Chapter 6

\title{
PCDDs/PCDFs and PCBs in Wastewater and Sewage
}

\section{Sludge}

\author{
Magdalena Urbaniak and Anna Wyrwicka
}

Additional information is available at the end of the chapter

http://dx.doi.org/10.5772/66204

\begin{abstract}
The chapter includes the information concerning the wastewater treatment plants (WWTPs) functioning in respect to polychlorinated dibenzo-p-dioxins (PCDDs)/ polychlorinated dibenzofurans (PCDFs) and polychlorinated biphenyls (PCBs). In particular, the chapter describes the occurrence and fate of PCDDs/PCDFs and PCBs in WWTPs, at different treatment stages, including the tertiary wastewater treatment (e.g. constructed, wetlands biofilters) and factors affecting the removal of these micropollutants during treatment process. Considering the production of growing amounts of sewage sludge as an end product of the wastewater treatment process, the chapter describes also the occurrence and fate of above-mentioned compounds in sewage sludge and the ways of their utilization with the special emphasis on agricultural uses, bioremediation and phytoremediation processes. With regard to the agricultural use of sewage sludge, the impact of sludge-born PCDDs/PCDFs and PCBs on plant growth and plant metabolism is described, together with the current state of knowledge on the accumulation and translocation of the studied compounds in plant tissues.
\end{abstract}

Keywords: PCDDs/PCDFs, PCBs, wastewater, sewage sludge, phytoremediation, plant growth, plant metabolism

\section{Introduction}

Rapid growth in global population has been observed from approximately 5.3 billion in 1992 [1] to about 6.97 billion in 2011 [2]. United Nation predicted that in 2030, the global population reach over 8 billion, whereas in 2050 exceed 9 billion. The growing population affect the consumption of water and consequential production of wastewater. The projections 
concerning influent wastewater flow in USA estimate its rise from 100,000,000 m³/day in 1996 to $170,000,000 \mathrm{~m}^{3} /$ day in 2025 [3-5].

An increased usage of water around the world led to an increased concern about the outgoing wastewater quality from municipal wastewater treatment plants (WWTPs) [6]. Usually, quantification of wastewater quality is based on monitoring of traditional parameters which can be analysed in easy and inexpensive way and are regulated by the European Urban Wastewater Directive (91/271/EEC). These parameters include biochemical oxygen demand (BOD), chemical oxygen demand (COD), nitrates, phosphates and total suspended solids [7]. Nevertheless, these routine chemical analyses cannot give a complete overview of the threat to the water environment posed by other substances released through the WWTPs effluents such as polychlorinated dibenzo- $p$-dioxins (PCDDs), polychlorinated dibenzofurans (PCDFs) and polychlorinated biphenyls (PCBs), which are toxic, carcinogenic and known endocrine disrupters posing a serious risk for living organisms [6]. According the Directive of the European Parliament and the Council 2013/39/EC of 12 August 2013 amending Directive 2000/60/EC and 2008/105/EC in respect of priority substances in the field of water policy, PCDDs/PCDFs and PCBs have been identified as priority hazardous substances, which need to be eliminated from the water environment.

Considering the above, the present chapter reviews the available data concerning the occurrence and fate of PCDDs/PCDFs and PCBs in wastewater (point 2) and sewage sludge (point 3) with the special emphasis of the ways of sewage sludge utilization and impact of sludgeborn PCDDs/PCDFs and PCBs on the plant growth and plant metabolism.

\section{The occurrence and fate of PCDDs/PCDFs and PCBs in WWTPs}

WWTPs represent an obligatory and final step prior to the release of wastewater into the environment. Hence, an emerging task for WWTPs would be to act as a barrier for micropollutants, preventing the emission of potentially harmful substances into the aqueous environment. WWTPs use different kinds of methods including biological, physical and chemical processes, to fulfil the regulatory standards regarding the quality of the effluent discharges. Regardless of the methods used at any particular WWTP, all the treatment processes can be generally divided into three categories: (1) primary, (2) secondary and (3) advanced tertiary treatment [5]. The primary treatment removes large objects from incoming wastewater through floatation, settling and screening mechanisms and the smaller objects such as sand are removed in grit chambers and sedimentations tanks. The secondary treatment is designed to substantially degrade organic matter and dissolved nutrients using trickling filters and activated sludge. The purpose of the tertiary treatment is to further improve the effluent quality before it is discharged to the receiving environment and include filtration, chlorination and UV radiation.

The occurrence of PCDDs/PCDFs and PCBs in the untreated wastewater and sewage sludge has been studied very intensively during recent decades and revealed their very high concentrations with a predominance of highly chlorinated congeners [8-15]. 
The available literature data indicate that conventional wastewater treatment systems are not able to sufficiently remove hydrophobic contaminants, which have adverse effects on the receiving water ecosystem $[5,7,13]$. Thus, organic compounds are detected in the river water worldwide [13, 16-22]. This is due to the fact that for many years, quantification of wastewater effluents and receiving river water pollution were restricted to monitor biochemical oxygen demand (BOD), chemical oxygen demand (COD), nitrogen and phosphorus concentrations and total suspended solids [7]. However, as shown in the work of Urbaniak et al. [13] and Urbaniak and Kiedrzyńska [14], significant concentrations of PCDDs/PCDFs and PCBs may be present in treated wastewater, with the highest values in the smallest WWTPs. All WWTPs studied by Urbaniak et al. [13] were found to discharge toxic PCDD/PCDF and PCB compounds into their receiving rivers. This is the effect of insufficient regulation of the discharge of toxic congeners of PCDDs/PCDFs by municipal WWTPs: the existing regulations only apply to municipal WWTPs with a population equivalent (p.e.) of 100,000. In consequence, the release of PCDDs/PCDFs in treated wastewater from the studied WWTPs is not regulated, as the plants are below this p.e. This, together with the increasing number of municipal WWTPs, and the results presented by Sztamberek-Gola et al. [23] and Oleszek-Kudlak et al. [24], which demonstrate increases in the concentrations of the lower chlorinated, and hence, more toxic, PCDDs/PCDFs in WWTP outlet water, may result in lower quality of the receiving waters. Data presented by Sztamberek-Gola et al. [23] and Oleszek-Kudlak et al. [24] obtained on the basis of three WWTP analyses, revealed total and toxic equivalency (TEQ) concentrations within the range of $107.26-219.19 \mathrm{pg} / \mathrm{m}^{3}$ for total PCDDs, from 201.75 to $736.50 \mathrm{pg} / \mathrm{m}^{3}$ for total PCDFs and from 14.70 to $116.40 \mathrm{pg}$ I-TEQ/m³ $\mathrm{m}^{3}$ for TEQ. Moreover, the authors observed increased PCDD and PCDF concentrations to be related to increased daily wastewater flow: the lowest values were noted in effluents from the smallest WTP, with a daily flow of $20,000 \mathrm{~m}^{3}$, whereas samples coming from WWTPs with twice the flow $\left(40,000\right.$ and $\left.45,000 \mathrm{~m}^{3}\right)$ were found to have concentrations about two times higher. Considering the above results, the authors note that wastewater treatment affects the fate of PCDDs/PCDFs, with increased amounts of lower chlorinated, and thus more toxic, congeners in the outlet effluents. As a consequence, the International-TEQ (I-TEQ) concentrations are more than five times higher in the outgoing treated effluent than the incoming wastewater. Moreover, the authors observe a predominance of PCDFs over PCDDs in the outgoing effluents. Also other studies confirm the presence of PCDDs/PCDFs in wastewater effluents. The study of Rappe et al. [10] showed that the TEQ and PCDD/PCDF concentrations in wastewater effluents from publicly owned treatment works ranged between 0.264 and $3.84 \mathrm{pg}$ TEQ/L. Urbaniak et al. [13] examined 17 outflows of treated wastewater from municipal wastewater treatment plants. Sewage treatment plants were divided into three classes based on their p.e. size, that is: class I (0-1999 p.e.), class II (2000-9999 p.e.), class III (10,000-14,999 p.e.) and class IV (15,00099,999 p.e.). The analysis of the treated wastewater collected at the sewage outlets revealed that toxic PCDDs/PCDFs and dl-PCBs were present at a range of concentrations from 32.30 to $732.79 \mathrm{pg} / \mathrm{L}$. The mean values at high water flow and during stable hydrological conditions were respectively 81.96 and $216.92 \mathrm{pg} / \mathrm{L}$ for class I wastewater treatment plants, 80.47 and $74.30 \mathrm{pg} / \mathrm{L}$ for class II, and 69.82 and $137.06 \mathrm{pg} / \mathrm{L}$ for class IV. These results indicate 
that small wastewater treatment plants had higher concentrations of the studied compounds than the larger ones. In the case of the concentrations measured as TEQs, the obtained values were less diverse, amounting to 4.38 and $3.81 \mathrm{pg}$ TEQ/L for high and stable flow in class I wastewater treatment plants, 4.72 and $3.97 \mathrm{pg}$ TEQ/L for class II, and 3.94 and $3.15 \mathrm{pg}$ TEQ/L for class IV.

With reference to the PCBs, only a few publications refer to their concentrations in the WWTPs effluents. Katsoyiannis and Samara [25, 26] demonstrated the occurrence of the sum of indicator PCBs ( $\left.\sum 7 \mathrm{PCBs}\right)$ in the raw urban wastewater and wastewater after primary and secondary treatment steps. The authors showed decreasing mean concentrations of $\sum 7 \mathrm{PCBs}$ from $1,000,000$ through 631,000 to $250,000 \mathrm{pg} / \mathrm{L}$ in raw wastewater and effluents from primary and secondary treatment stage, respectively. Another research conducted by Blanchard et al. [27] in the outflow from the Montreal WTP (Canada) showed much lower concentrations (measured as sum of 13 PCB congeners) ranged from 20 to $860 \mathrm{pg} / \mathrm{L}$ with the mean value of 310 pg/L, whereas Pham and Prolux [28] found a concentration of $\Sigma 13$ PCBs in the treated wastewater from the same WTP of $1400 \mathrm{pg} / \mathrm{L}$. The study of Bergqvist et al. [6] conducted in two WTPs in Umea (Sweden) and in Siauliai (Lithuania) showed higher $\sum 7 \mathrm{PCB}$ ranged from 1000 to $6000 \mathrm{pg} / \mathrm{L}$. The authors also demonstrated a rapid increase of the $\sum 7 \mathrm{PCBs}$ during the treatment process (ranged from 300 to $1000 \mathrm{pg} / \mathrm{L}$ and from 1000 to $6000 \mathrm{pg} / \mathrm{L}$ in the case of Umea and Siauliai WTP, respectively). However, other authors suggest that treatment processes such as sorption to the sludge remove up to $70 \%$ of PCBs, whereas volatilization led to eliminate of about 50\% of the Aroclor 1254 [29, 30]. According to Pham and Prolux, 1997, the removal rates ranged from $33 \%$ (for PCB: 101) up to $100 \%$ (for PCB: 194) with the average value for the $\sum 13 \mathrm{PCBs}$ of $67 \%$. Despite the above, Urbaniak and Kiedrzyńska [14] note that the treated wastewater effluent of the smallest wastewater treatment plants, class I, is characterized by dlPCB values more than double those of medium and large wastewater plants. This phenomenon was not noted for TEQ values, which were found in the narrow range of $0.31-0.37 \mathrm{pg}$ TEQ/L. The study of Urbaniak and Kiedrzyńska [14] demonstrates a significant problem with the maintenance of the proper purification efficiency in all the studied WWTPs and in this way effluents quality which have the potential to affect the quality of river water.

In order to enhance the removal of PCDDs/PCDFs and PCBs from wastewater effluents and the receiving river waters, the land-water ecotones constructed in a river valley with different kinds of plants and micro-organisms may be applied. Such structures may partially purify the inflowing surface water and groundwater contaminated by PCDDs/PCDFs and PCBs through their capturing, immobilization and/or degradation [31-33]. Wetlands are another promising solution towards wastewater purification due to their intrinsic function to transform and store organic matter and nutrients [34,35] and associated micropollutants such as PCDDs/PCDFs and PCBs. Due to these properties, wetlands have been used for water quality improvement worldwide [36]. Constructed wetlands were first used for treatment of wastewater in the 1950s, while in last years, they are also used for treatment of runoff water from city areas and agriculture. Constructed wetlands exploit natural processes to remove pollutants in a sustainable cost and in an energy effective way with minimal operation and maintenance cost. 
Moreover, their usage as tools in the treatment of polluted waters has been gaining popularity as an ecological engineering alternative over conventional, chemical-based methods.

The promising solution provides ecohydrology [37], through the use of cascade system of biofilters for the purification of wastewater, runoff water, leachate, etc. The biofilters which consist with zone of intensive sedimentation, which facilitate the deposition of matter, nutrients and micropollutants and their further biodegradation by existing microbiota and macrophyte zone where an intensive phytodegradation processes occur, are considered to be one of the most effective solutions for pollutant removal. Our earlier results obtained on the basis of such systems functioning in the urban area and receiving the untreated sewage and storm water (Sokołówka River, Poland) showed the removal efficiency reaching 95\% for mineral matter, $86 \%$ for organic matter, $81 \%$ for total nitrogen and $86 \%$ for total phosphorus [38]. At the same time, removal efficiency of biofilter located in rural area (Asella lake, Ethiopia) was $67 \%, 36 \%, 76 \%$ and $93 \%$ for mineral matter, organic matter, total nitrogen and total phosphorus, respectively [38]. Moreover, results from the biofilter located in Asella (Central Ethiopia) demonstrated a 70\% reduction of the lake sediment TEQ after one year of biofilter implementation (data not published). The implementation of such biofiltration system enabled a reduction in the input of micropollutants into the river recipients through sedimentation and acceleration of biodegradation and phytodegradation processes and in this way indicates the positive role of such systems in the quality of water ecosystems and in consequence of human health.

\section{The occurrence and fate of PCDDs/PCDFs and PCBs in sewage sludge and sewage sludge amended soil}

The occurrence of PCDDs/PCDFs and PCBs in inflowing wastewater causes considerable problems for the WWTPs because conventional biological and chemical processes are insufficient for removing them. What is more is scarce data exist to explain how wastewater treatment affects the behaviour and fate of PCDDs/PCDFs and PCBs. Since they have a very high sorption potential [39], they are expected to partition into the sewage sludge part of the wastewater during treatment processes. In addition, the majority of treatment processes are very conducive to volatilization; hence, low volatilization potentials of PCDDs/PCDFs reduce their loss [24].

Various studies confirm that sewage sludge contains a very high level of PCDDs/PCDFs and PCBs ranging between 2.26 and $1270 \mathrm{ng}$ I-TEQ/kg in the United States [10], from 19 to $225 \mathrm{ng}$ I-TEQ/kg in UK [40], from 7 to $160 \mathrm{ng}$ I-TEQ/kg in Spain [41], and between 16.85 and 74.56 ng I-TEQ/kg in Poland [24, 42]. Our study from the Lodz Wastewater Treatment plant showed the concentration of 17 toxic congeners PCDDs/PCDF in sewage sludge equal to 3270.07 $\mathrm{ng} / \mathrm{kg}$ and the TEQ concentration equal to $29.71 \mathrm{ng} \mathrm{TEQ} / \mathrm{kg}$.

These findings confirm that the majority of PCDDs, PCDFs and PCBs are deposited in sludge. This in turn implicates problems with the further use of such contaminated sludge as a fertilizer especially because PCDDs/PCDFs and PCBs toxicity is further enhanced by their accumulation in soil, and bioaccumulation and biomagnification within food chains. 
Concerning the above, the further part of the chapter is focused on the methods dedicated to safe disposal and utilization of sewage sludge and the fate of sludge-born PCDDs/PCDFs and PCBs in the environment.

\section{Sewage sludge utilization}

The main methods of sewage sludge utilization include storage, natural resources and agricultural land use, and burning. At present, most often the sewage sludge is stored on sludge lagoons. This practice became insufficient because (1) the storage has a limited capacity and (2) sludge could be used as a potential recyclable material; however, this method requires drying of sewage sludge to the content of $58-95 \%$ dry weight (d.w.), which is high energyconsuming.

The use of thermal processes removes organic compounds associated with the sewage sludge but leave contaminated fly ash. Moreover, this kind of sewage sludge utilization led to air pollution and airborne diseases among human population due to smoke production which may contain toxic compounds like heavy metals. The use of efficient equipment led to the reduction of emissions of harmful elements to the atmosphere but at the same time move the problem of pollutant emissions to the captured ashes. Additionally, during the incineration process as an end by-product, the hydrogen $\left(\mathrm{H}_{2}\right)$, methane $\left(\mathrm{CH}_{4}\right)$, carbon monoxide $(\mathrm{CO})$ and carbon dioxide $\left(\mathrm{CO}_{2}\right)$ are produced. This led to increased production of greenhouse gases, which are the main concern of the Kyoto Protocol regarding climate change.

The alternative method of sewage sludge utilization is their use as a soil and plant fertilizer. This way of their utilization is possible thanks to high organic matter content and high levels of nitrogen and phosphorus which are required for plant growth [43, 44]. Moreover, the organic matter increases the water capacity influences by this way positive on the structure, texture and microbial activity of the soil. The use of sewage sludge as a fertilizer is widespread [9]. The amount of sludge used for agricultural purpose is $25 \%$ in Germany and up to $90 \%$ in Sweden [9].

The use of sewage sludge as plant fertilizer is not only the method of sewage sludge management but also the method for implementation of the Renewable Energy Sources Directivewhen using energetic crops (2001/77/EC) and the Kyoto Protocol (OJ L 203 of 2005, p.1684). Moreover, crops may be used for the reduction of enhanced pollutants levels in soil after sludge application.

Following application, the sludge is present in relatively thin film on the soil surface. Nevertheless, it should be stated that due to high persistence of the PCDDs/PCDFs and PCBs, the addition of these compounds to the soil through the application of sludge must lead to an increase in soil contamination. This is important because Regulation of the Ministry of Environment of Poland from 16 April 2002 recommended to not exceed the $20 \mathrm{ng}$ PCB/g d.w. in agricultural soil (PCB: 28, 52, 101, 118, 138, 153 and 180) and $2000 \mathrm{ng}$ PCB/g d.w. in industrial soil (OJ 2002, 63 item 634). Nevertheless, there is no law regulation concerning the 
concentrations of 17 toxic congeners of PCDD, PCDF and 12 toxic dl-PCB in soil. In contrast, in Germany, the limit for PCB is $0.4,2.0,0.8$ and $40.0 \mathrm{mg} / \mathrm{kg}$ d.w. for playgrounds, parks, residential and industrial areas, respectively [45]. The limit for PCDD/PCDF is the following: 100, 1000, 1000 and 10,000 ng TEQ/kg d.w. for playgrounds, parks, residential and industrial areas, respectively [46].

In case of sewage sludge, the Directive 86/278/EEC on the protection of the environment, and in particular of the soil when sewage sludge is used in agriculture, does not provide any limit values or requirements for organic compounds in sewage sludge. Thus, several national regulations on the use of sludge have added specifications on organic compounds. This is the case in particular of Austria, France and Germany which have all included limit values for some organic compounds in the relevant regulation for the use of sludge, for example, in Austria, the limit values for PCDDs/PCDFs in sewage sludge are $100 \mathrm{ng}$ TEQ/kg d.w. in Lower and Upper Austria and Burgenland and $50 \mathrm{ng}$ TEQ/kg d.w. in Carinthia [47]. The limit of 100 ng TEQ/kg d.w. is also valid in Germany [48]. The limits for PCBs in sewage sludge are the following: $0.2 \mathrm{mg} / \mathrm{kg}$ d.w. in Lower and Upper Austria and Burgenland and $1.0 \mathrm{mg} / \mathrm{kg}$ d.w. in Burgenland. In France, the limit for sum of seven principal PCBs (PCB 28, 52, 101, 118, 138, 153,180 ) is $0.8 \mathrm{mg} / \mathrm{kg}$ d.w.; in Germany is $0.2 \mathrm{mg} / \mathrm{kg}$ d.w. for each of the six PCB congeners; and in Sweden is $0.4 \mathrm{mg} / \mathrm{kg}$ d.w. In Poland, according to Ministerial Decree (OJ 2009, 27 item 169), PCBs should be completely removed from the sewage during their treatment; nevertheless, there is no limits of the aforementioned compounds in sewage sludge.

Despite the above national regulation, European Union proposed some limit values for concentrations of organic compounds and PCDDs/PCDFs in sludge for use on land. The mentioned proposed limit values are following: $0.8 \mathrm{mg} / \mathrm{kg}$ of dry matter for PCBs (sum of PCBs 28, 52, 101, 118, 138, 153 and 180) and $100 \mathrm{ng}$ TEQ/kg of dry matter for PCDDs/PCDFs [49]. Also the US EPA proposed the limit of $300 \mathrm{ng}$ TEQ/kg of dry matter for 17 toxic PCDDs/PCDFs and 12 coplanar PCBs [50].

\section{Bioremediation and phytoremediation of sludge originated PCDDs/ PCDFs and PCBs in soil}

Reports on the biodegradation of chlorinated dioxins in the soil are contradicting. On the one hand, there are studies that indicate that chlorinated PCDDs/PCDFs are persistent. One of such studies considered chlorinated PCDDs/PCDFs that were introduced into soil through land application of sewage sludge [51]. According to this study, the PCDDs/PCDFs concentrations did not change significantly after 260 days of monitoring. On the other hand, the evidence obtained in other experiments suggests that PCDDs/PCDFs are degraded in soil, for example, the concentration of 2,3,7,8-TCDD was monitored over 10 years in the soil and was shown to be significantly decrease. Biodegradation was also observed in the soil spiked with one to $100 \mathrm{ppm}$ of 2,3,7,8-TCDD. Between 37 and 44\% of added 2,3,7,8-TCDD was eliminated during 1 year [52]. 
The above results are connected with the soil microbial transformation of micropollutants. Many literature data suggest that microbial biodegradation is the critical event determining the fate and persistence of PCDDs/PCDFs in the soil [53].

Biodegradation is dependent on micro-organism enzymes which modify toxic compounds into less toxic forms. Biodegradation can be carried as two processes: mineralization, when organic compound uses a sole source of carbon and energy by micro-organisms, and cometabolism where transformation of given pollutant depends on the presence of other substrate. Products of this process can be further mineralized; otherwise, incomplete degradation occurs, leading to a formation and accumulation of metabolites more toxic than parent substrates.

In this place, there is a need to underline the role of humic acids-major components of soil organic matter which consist of complex polymers of hydroxyphenols, hydroxybenzoic and methoxybenzoic acids and other aromatic structures with linked peptides, amino sugar compounds, fatty acids and possibly other constituents. Hydroquinone/quinone-type couples are perceived to affect the redox properties of humic acid and to act either as electron transfer mediators or as direct donors of electrons. Thus, the amount of humic acids may determine the microbial dechlorination of PCDDs/PCDFs [54].

The use of anaerobic and aerobic micro-organisms is the only known process of PCDDs/PCDFs degradation in soil and aquatic systems, leading to a removal of chlorine atoms from the biphenyl molecule and theoretically releasing $\mathrm{CO}_{2}$, chlorine and water. Highly chlorinated congeners have been found to be reductively dechlorinated under anaerobic conditions through a preferential meta- and para-chlorine removal and production of less chlorinated congeners, which can then be used in aerobic transformations. Thus, complete degradation of PCDDs/PCDFs can be achieved by a sequential exposure to anaerobic and aerobic microorganisms [55].

The fungi, similarly to bacteria, are also capable to degrade $\mathrm{PCDD}_{\mathrm{s}} / \mathrm{PCDF}_{\mathrm{s}}$ in the presence of oxygen using both processes: mineralization and co-metabolism. The fungi use specific enzymes named lignin peroxidase or manganese peroxidase which enable to oxidize the pollutant molecule. The fungal aerobic biodegradation was first reported by Bumpus et al. [56]. The authors documented the mineralization of $\left[{ }^{14} \mathrm{C}\right] 2,3,7,8-\mathrm{TCDD}$ to ${ }^{14} \mathrm{CO}_{2}$ by Phanerochaete chrysosporium within 30 days. P. chrysosporium also successfully been used to degrade 2,7DCDD. It should also be mentioned that the biodegradation activity of fungi is not limited to less chlorinated congeners, for example, $P$. chrysosporium is able to remove 34 and $48 \%$ of a mixture of PCDD/PCDF congeners containing from 5 to 8 chlorine atoms in the molecule during 7 to 14 days [57].

It was estimated that the highest rate of microbial degradation of pollutants occurs in the plant rhizosphere $[58,59]$. Rhizodegradation of organic micropollutants is one of the most effective remediation processes due to existing interactions in the rhizosphere between plant roots, plant exudates, soil and micro-organisms. Moreover, plants are able to store in their rhizosphere up to $40 \%$ of aminoacids, carbohydrates and other photosynthesis products. This influences on the availability of carbon used by micro-organisms in the co-metabolism process. 
Whipps [60] demonstrated that $1 \mathrm{~g}$ of planted soil contains $10^{12}$ higher amount of microorganisms in comparison with non-planted one. Rhizosphere microbiota plays also an intrinsic role in the protection of plants against pathogens and stress caused by too high concentration of pollutants and eases the uptake of biogenic substances by a given plant [61]. The effectiveness of rhizosphere biodegradation depends on the ability of micro-organisms to adapt to a given pollution concentration and effectiveness of colonization of roots [61]. The study of Kuiper et al. [62] demonstrated that naturally occurred rhizosphere biodegradation may be enhanced by an addition of micro-organisms to the rhizosphere.

The study with application of plants for phytoremediation/rhizoremediation of soil contaminated with organic compounds showed the decline in the concentration of organochlorine compounds of $30 \%$ during 2 years of plant cultivation. At the same time, the unplanted soil demonstrated the reduction of about two times lower [63]. On the basis of 21-month study, Nedunuri et al. [64] showed the decrease of aromatic compounds concentrations of about 42 and $50 \%$ in soil cultivated with fibre flax (Lolium annual) and St. Augustine grass (Stenotaphrum secundatum), respectively. Other examples showed phytoremediation of soil contaminated with crude oil using combination of grass and fertilizers [64-66]. Despite grasses, the shrubs and trees can be also used as effective phytoremediation tools. The example can be the study of Vervaeke et al. [67] who reported 57\% reduction of aromatic compounds and mineral oils during 1.5 years of willow (Salix viminalis) cultivation.

With respect to the removal of sludge-born PCBs, Wyrwicka et al. [68] demonstrated that the use of cucumber (Cucumis sativus L. var. Cezar) resulted in a decrease in PCB concentrations by an average of $38.63 \%$. However, the efficiency of PCB removal decreased as the dose of sludge increased in sludge-treated soil $(41.28,38.39$ and $36.22 \%$ PCB reduction at doses of 3, 9 and 18 tonnes/ha). Urbaniak et al. [43] demonstrated that the use of other plant from the Cucurbitaceae family-Cucurbita pepo L. cv Atena Polka-reduced total PCDDs/PCDFs and TEQ concentration by 37 and $68 \%$, respectively, in soil amended with sewage sludge. The comparative study of the use of Cucurbita pepo L. cv Atena Polka (zucchini) and Cucumis sativus L. var. Cezar (cucumber) showed that zucchini was more efficient in sludge-born PCDDs/ PCDFs removal, while cucumber demonstrated higher efficiency in soil phytotoxicity alleviation [44]. Presented studies demonstrate that cultivation of the plants from the Cucurbitaceae family plays a positive role in reducing the PCDDs/PCDFS in soil amended with sewage sludge.

The above data confirm the positive role of plant-bacteria systems in the removal of PCDDs/ PCDFs and PCBs from soil contaminated through agricultural utilization of sewage sludge.

\section{Impact of PCDDs/PCDFs on plant growth and plant metabolism}

There is limited data on the impact of PCDDs/PCDFs on the plant growth and biomass production. The literature on this issue mainly comes from studies on the effects of sewage sludge on plant growth and metabolism [69-71]. Application of sewage sludge as soil organic amendment and as a source of macronutrients and micronutrients can contribute not only to 
restore the soil cover and vegetation on devastated land [72] but also can be used in the organization and maintenance of green areas in cities and recreational facilities. An important aspect of the use of sewage sludge is to improve soil fertility, of low quality class, which can be used, for example, for energy crops (biomass extraction). The addition of sewage sludge may have beneficial effects on plants and soil expressing itself by improving the physicochemical properties of the soil, increased nutrient content for plants, increased production of plant biomass, and increased activity of soil enzymes and soil micro-organisms [73]. However, the presence of pollutants in sewage sludge may have a negative impact on the growth and development of plants. The content of heavy metals, toxic organic compounds including PCDDs/PCDFs and microbiological contaminants may contribute to the occurrence of secondary oxidative stress [74-76]. The occurrence of environmental stresses can lead to an imbalance in cellular redox state and predominance of oxidation reaction over reduction reactions. The reactive oxygen species (ROS) are highly reactive and toxic and can damage important from the biological point of view molecules such as nucleic acids, proteins and lipids [77]. It is well known that oxidative stress is a common plant reaction to numerous biotic [78] and abiotic stresses including drought [79], high salinity [80], temperature extremes [81, 82], anoxia [83], mineral nutrients' deficiencies and metal toxicity [84], increased UV-B radiation [85], gaseous pollutants [86], acid rain [87] and PCDD/PCDFs [88].

The enzymatic and non-enzymatic antioxidant systems present in the plant tissues prevent the accumulation of ROS caused by stress factors. The enzymatic free radical scavengers include, among others, superoxide dismutase (SOD), catalase (CAT) and peroxidases; ascorbate peroxidase $(\mathrm{APx})$, glutathione peroxidase (GSH-Px), phenolic peroxidase (POx). Nonenzymatic, low molecular weight antioxidants mainly include ascorbic acid, glutathione, carotenoids, flavonoids, $\alpha$-tocopherol and the phenolic compounds [89, 90].

Currently, there is little literature concerning the impact of PCDDs/PCDFs and PCBs on plant antioxidative system, and usually, information are related to multistress associated with the presence of organic pollutants and heavy metals. The plants belonging to the Cucurbitaceae family are known to accumulate high levels of PCDDs/PCDFs and PCBs compared with other plant species. However, the studies showed also that plant belonging to cucurbits: zucchini and cucumber, activate the antioxidative system and detoxification mechanisms as an effect of application of sewage sludge containing high levels of POPs including PCDDs/PCDFs and PCB $[68,91]$. Obtained results indicate that signs of sewage sludge toxicity were greater in zucchini than in cucumber plants. Visible symptoms of leaf blade damage after sewage sludge application occurred only on the zucchini plants. Activity of peroxidases such as ascorbate peroxidase (APx) and guaiacol peroxidase (POx) increased in zucchini plants significantly with increasing of sewage sludge dose, but they decreased in cucumber plants. Moreover, both in zucchini and cucumber plants, the relationship between peroxidases activity and catalase (CAT) activity was inverse. Activity of detoxifying enzyme-glutathione S-transferase (GST) -increased progressively with the sludge concentration in both the zucchini and cucumber leaves. Moreover, the increase in GST activity was greater in zucchini plants and was visible at the lowest dose used. Concentration of $\alpha$-tocopherol, a lipophilic antioxidant, increased with sewage sludge dose in both investigated species. 
Other research focused on the influence of light soil fertilization using sewage sludge on soil toxicity showed its negative impact on growth and development of three plant species Lepidium sativum, Sorgo saccharatum and Sinapis alba [92].

\section{Accumulation and translocation of PCDDs/PCDFs and PCBs in plant tissue}

Plants are the organisms, which are the first stage in the food chain. Widely distributed at low concentration in the environment, extraordinary toxic PCDDs/PCDFs and PCBs have the ability to bioaccumulate in the food chain. For these reasons, accumulation of these compounds by plants is an important step for the transfer of PCDDs/PCDFs and PCBs into the higher trophic levels and biomagnification. Understanding the mechanisms of uptake and translocation of PCDDs/PCDFs and PCBs allows to control the risk of unexpected contamination of important vegetative plants. On the other hand, this knowledge can be used as a tool for selecting plants that have high phytoremediative potential $[59,93]$.

The accumulation of persistent pollutants such as chlorinated pesticides, chlorobenzenes, PCBs and PAH as well as PCDDs/PCDFs in vegetation has been demonstrated in several investigations carried out in the 1980s of the twentieth century [94-96]. In recent years, our understanding of the uptake of PCDDs/PCDFs by plants increased considerably $[97,98]$ but the pathway by which above-mentioned organic pollutants enter to the plant tissues still remain under discussion. Early evidence suggested that organic compounds were unlikely to be taken up from soil and translocated within the plants due to their hydrophobicity [99]. Nevertheless, according to many publications, the absorption from soil vapour may be the major pathway by which PCDDs/PCDFs from soil enter into the aerial plant tissues [100-102]. Other studies also evidence that dry gaseous deposition is the dominant pathway of PCDDs/ PCDFs in plant tissue, such as lettuce, potato, apple, pear, rice, pea and oilseed rape [103108]. However, more recent studies have shown that some species of plant have the ability to mobilize and accumulate significant concentrations of several organic compounds from soil. Generally, it is estimated that there are several pathways of PCDDs/PCDFs and PCBs accumulation in plants: (1) adsorption to the root surface, (2) root uptake trough absorption from soil vapour or water phases of soil and translocation to upper plant organs, (3) contamination of the foliage and fruits by soil particles which develop in contact with or in close proximity to the ground, (4) absorption of volatilized from soil PCDDs/PCDFs and PCBs by aerial plants parts, (5) atmospheric deposition of airborne PCDDs/PCDFs and PCBs for both gas and particle phase [97, 109].

Uptake and distribution of PCDDs/PCDFs and PCBs are a function of chemical and physical properties of particular pollutant, such as hydrophobicity, water solubility and vapour pressure, as well as environmental conditions, such as temperature, $\mathrm{pH}$, organic carbon content of the soil and plant species [110].

The most important property which determines the possibility of absorption of various compounds from the soil by roots is hydrophobicity. Usually, it is expressed as the 1-octanol/ 
water partition coefficients $\left(\mathrm{K}_{\mathrm{ow}}\right)$ and extends over a wide range for different organic compounds [111]. $\mathrm{K}_{\mathrm{ow}}$ values vary over several orders of magnitude and are expressed as $\log \mathrm{K}_{\mathrm{ow}}$. More hydrophobic substances that having a higher $\log \mathrm{K}_{\mathrm{ow}}$ value are sorbed more strongly to soil organic particles. In consequences, if the $\log \mathrm{K}_{\mathrm{ow}}$ value of the compound is around 2, the compound could be easily absorbed by plants, whereas if the $\log \mathrm{K}_{\mathrm{ow}}$ value is over 5 , the compound is hardly absorbed $[112,113]$. The value closely related to the hydrophobicity is solubility. Water solubility describes the amount of a chemical which can dissolve in a known quantity of water. The solubility of the chemical compound is dependent on temperature and is $\mathrm{pH}$-dependent. Another feature describing the tendency of the substance to move from the aqueous phase to the gas phase is Henry's constant $\left(\mathrm{H}_{c}\right)$. This parameter can be useful in predicting the ability of chemical to volatilize from soil, water or plant surfaces into the atmosphere. Although chemical properties are important predictors of uptake, the physiology and composition of the plant root itself are also a significant influence. One explanation for such difference in uptake potential is the varying types and amounts of lipids in roots cells.

The uptake of organic chemicals by plants is also influenced by soil properties. Transfer of organic pollutants from soil to plant roots might be carried out by the uptake of soil pore water during plant transpiration. Non-ionized organic pollutants, which usually are lipophilic, are principally sorbed or bound to several components in soil including clays, iron oxides and onto the organic fraction of the soil's solid phase. The latter usually exerts the strongest influence on the organic chemicals pore water concentration [114]. Similarly, compounds with a high $\log \mathrm{K}_{\mathrm{ow}}$ associate with particulates in the wastewater and become incorporated into sewage sludge during sedimentation, and thus, substances with a $\log \mathrm{K}_{\mathrm{ow}}$ of $<2.0$ appear less frequently in sewage sludge. It is considered that with the increase in the organic matter content of a soil, the proportion of the chemical in the pore water decreases, and consequently, its uptake by plant also decreases. Moreover, it should be noted that the increase of the amount of organic carbon fraction reduces the optimum of $\mathrm{K}_{\mathrm{ow}}$ for uptake into plants.

Deposition of non-ionic organic compounds on leaves and its sorption at the leaf surface or rapid movement into the leaf depends on diffusion through the cuticle or stomata. The concentration of all these compounds on leaves is mainly due to adsorption from the gaseous phase. Accumulation of PCDDs/PCDFs in above-ground plant parts mainly results from atmospheric deposition in the gaseous state alone. The contribution of particle-bound deposition may be, despite areas of extreme particle loading, of secondary importance [94].

The pathways of PCDDs/PCDFs accumulation in rice plants were carefully examined by Uegaki et al., [105] who estimated that dioxins were not absorbed from the soil by growing plants, but its uptake from atmosphere has the greatest importance. They reported that dioxin levels in rice plants were strongly influenced by soil adhesion but only at the early growth stage of brown rice plants grown in three different soils: dioxin-contaminated soil, paddy soil and upland soil. In the later stage of growth, over the time of experiment, predominant influence on dioxin level in rice leaf and steam was attributed to concentrations of these compounds in atmospheric gas phase. This remarks remain in agree with results other investigations which indicate that approximately $70 \%$ of 2,3,7,8-TCDD added to the growth solution, but only $3 \%$ of 2-chlorobiphenyl was adsorbed by the roots of soybean and corn [108], 
and the most important mechanism of foliar contamination is connected with volatility of 2,3,7,8-TCDD from the growth solution.

Taking above relations into consideration, the hydrophobic nature of PCDDs/PCDFs and PCBs $\left(\log \mathrm{K}_{\mathrm{ow}}\right.$ values between 4.8 and 10.5) and their consequent strong adsorption to soil particles renders them to largely immobile and generally unavailable to plants $[115,116]$. The majority of available evidence nevertheless suggests that the adsorption or absorption of PCDDs/PCDFs and PCBs into plant roots and their subsequent translocation into other parts of the plant structure is minimal. However, the notable exceptions are several plants of the genus Cucurbita, which readily take up PCDDs/PCDFs from soil and translocate them to leaves and fruits $[97,117]$. It was also found that Cucurbita plants (e.g. zucchini, pumpkin and squash) can phytoextract polychlorinated biphenyls (PCBs) [118, 119], p,p' DDE [120, 121] and chlordane $[122,123]$ from soil and translocate some quantities to aerial tissues, as well as it was found that there is remarkable diversity in the uptake and transportation of persistent organic pollutants (POPs) among subspecies [119, 121, 123]. In case of willow, study of Oleszczuk and Baran [124] demonstrated the uptake of 16 Polycyclic aromatic hydrocarbons (PAHs) by willow from the soil amendment with the contaminated sewage sludge. The authors showed that soil total (PAHs) content decreased significantly within the first half year, followed by minimal changes over the subsequent 3 years of treatment. The authors showed that the total content of (PAHs) in control ranged between $3.6-7.3 \mu \mathrm{g} / \mathrm{kg}$ in shoots and $13-27 \mu \mathrm{g} / \mathrm{kg}$ in leaves, whereas treated plant demonstrated higher concentrations ranged from 5.5 to 17.6 and 13.5 to $33.8 \mu \mathrm{g} / \mathrm{kg}$ in shoots and leaves, respectively.

\section{Conclusions}

PCDDs/PCDFs and PCBs pose one of the most challenging problems in environmental science and technology. Their discharges via insufficiently treated wastewater are responsible for their occurrence in river ecosystems, both water and bottom sediments. The administration of sewage sludge, as end products of purification processes, additionally generates problems with the occurrence of PCDDs/PCDFs and PCBs in the environment and creates risk for ecosystem functioning and human well-being. Despite the above, the available literature data concerning PCDDs/PCDFs and PCBs removal from the environment using range of bio- and phytoremediation technologies demonstrate a promising tool towards safe and effective elimination of the compounds and in this way improvement of ecosystems quality.

\section{Acknowledgements}

The research is financed within the project 'Impact of sludge originated PCDDs/PCDFs on soil contamination and Salix sp. Metabolism' (UMO-2013/09/D/ST10/04043) and the project funded under the Ministry of Science and Higher Education programme under the name 'Iuventus Plus' for the years 2015-2017: project no. IP2014 049273. 


\section{Author details}

Magdalena Urbaniak ${ }^{1,2^{*}}$ and Anna Wyrwicka ${ }^{3}$

*Address all correspondence to: m.urbaniak@unesco.lodz.pl

1 European Regional Centre for Ecohydrology of the Polish Academy of Sciences, Łódz, Poland

2 Department of Applied Ecology, Faculty of Biology and Environmental Protection, University of Łódz, Łódz, Poland

3 Department of Plant Physiology and Biochemistry, Faculty of Biology and Environmental Protection, University of Łódz, Łódz, Poland

\section{References}

[1] UNEP. The UN-Water Status Report on the Application of Integrated Approaches to Water Resources Management. 2012.

[2] United Nations, Department of Economic and Social Affairs, Population Division. World Population Prospects: The 2010 Revision, Highlights and Advance Tables. Working Paper No. ESA/P/WP.220. 2011.

[3] US EPA. Progress in water quality: an evaluation for the national investment in municipal wastewater treatment. EPA-832-R-00-008. Washington, DC, USA. 2000.

[4] USEPA.Clean watershedsneedssurvey 2004-report to congress.(http://water.epa.gov/ scitech/datait/databases/cwns/upload/2008_01_09_2004rtc_cwns2004rtc.pdf) 2004.

[5] Carey RO and Migliccio KW. Contribution of wastewater treatment plant effluents to nutrient dynamics in aquatic systems; a review. Environ Manag 2009;44:205-217.

[6] Bergqvist PA, Augulyte L, Jurjoniene V. PAH and PCB removal efficiencies in Umea (Sweden) and Sialial (Lithuania) municipal wastewater treatment plants. Water Air Soil Pollut 2006;175:291-303.

[7] Cirja M, Ivashechkin P, Schäffer A, Corvini PFX. Factors affecting the removal of organic micropollutants from wastewater in conventional treatment plants (CTP) and membrane bioreactors (MBR). Rev Environ Sci Biotechnol 2008;7:61-78.

[8] Alcock RE and Jones KC. Pentachlorophenol (PCP) and chloranil as PCDD/Fs sources to sewage sludge and sludge amended soils in the UK. Chemosphere 1997;35:23172330. 
[9] McLachlan MS, Horstmann M, Hinkel M. Polychlorinated dibenzo-p-dioxins and dibenzofurans in sewage sludge: sources and fate following sludge application to land. Sci Total Environ 1996;185:109-123.

[10] Rappe C, Bergek S, Fiedler H, Cooper K. PCDD and PCDF contamination in catfish feed from Arkansas, USA. Chemosphere 1998;36:2705-2720.

[11] Eljarrat E, Caixach J, Rivera J. Comparison of TEQ contributions from PCDDs, PCDFs and dioxin-like PCBs in sewage sludge from Catalonia (Spain). Chemosphere 2003;51:595-601.

[12] Koch M, Knoth W, Rotard W. Source identification of PCDD/Fs in a sewage treatment plant of s German village. Chemosphere 2001;43:737-741.

[13] Urbaniak M, Kiedrzyńska E, Kiedrzyński M, Mendra M, Grochowalski A. The impact of point sources of pollution on the transport of micropollutants along the River continuum. Hydrol Res 2014;45(3):391-410.

[14] Urbaniak M and Kiedrzynska E. Concentrations and toxic equivalency of polychlorinated biphenyls in polish wastewater treatment plant effluents. Bull Environ Contam Toxicol 2015;95:530-535.

[15] Urbaniak M, Kiedrzyńska E, Kiedrzyński M, Zieliński M, Grochowalski A. The role of hydrology in the polychlorinated dibenzo-p-dioxin and dibenzofuran distributions in a lowland river. J Environ Qual 2015;44(4):1171-1182. doi:10.2134/jeq2014.10.0418

[16] Kakimoto H, Oka H, Miyata Y, Yonezawa Y, Niikawa A, Kyudo H, Tang N, Toriba A, Kizu R, Hayakawa K. Homologue and isomer distribution of dioxins observed In water samples collected from Kahokugata Lagoon and inflowing rivers, Japan. Water Res 2006;40:1929-1940.

[17] Chi KH, Hsu Sh-Ch, Lin Ch-Y, Kao ShJ, Lee TY. Deposition fluxes of PCDD/Fs in a reservoir system in northern Taiwan. Chemosphere 2011;83:745-752.

[18] Minomo K, Ohtsuka N, Hosono Sh, Nojiri K, Kawamura K. Seasonal change of PCDDs/ PCDFs/DL-PCBs in water of Ayase River, Japan: pollution sources and their contributions to TEQ. Chemosphere 2011;85:188-194.

[19] Kowalewska G, Konat-Stepowicz J, Wawrzyniak-Wydrowska B, Szymczyk-Żyła M. Transfer of organic contaminants to the Baltic in the Odra Estuary. Mar Pollut Bull 2003;46:703-718.

[20] Wolska I, Galer K, Namieśnik J. Transport and speciation of PAHs and PCBs in a river ecosystem. Pol J Environ Stud 2003;12(10):105-110.

[21] Urbaniak M, Kiedrzyńska E, Zalewski M. The role of a lowland reservoir in the transport of micropollutants, nutrients and the suspended particulate matter along the river continuum. Hydrol Res 2012;43(4):400-411.

[22] Urbaniak M, Skowron A, Zieliński M, Zalewski M. Hydrological and environment al conditions as key drivers for spatial and seasonal changes in PCDD/PCDF concentra- 
tions, transport and deposition along urban cascade reservoirs. Chemosphere 2012;88:1358-1367.

[23] Sztamberek-Gola I, Grochowalski A, Chrząszcz R. Monitoring of PCDDs, PCDFs and PAHs In waste-water with use the semipermeable membrane devices (SPMD). Organohalogen Compd 2003;60:45-48.

[24] Oleszek-Kudlak S, Grabda M, Czaplicka M, Rosik-Dulewska Cz, Shibata E, Takashi N. Fate of PCDD/PCDF turing mechanical-biological sludge treatment. Chemosphere 2005;62:389-397.

[25] Katsoyiannias A, Samara C. Persistent organic pollutants (POPs) in the sewage treatment plant in Thessaloniki, Northern Greece: occurrence and removal. Water Res 2004;38:2685-2698.

[26] Katsoyiannis A, Samara C. Persistent organic pollutants (POPs) in the conventional activated sludge treatment process: fate and mass balance. Environ Res 2005;97:245257.

[27] Blanchard M, Teil MJ, Ollivon D, Garban B, Chesterikoff C, Chevreuil M. Origin and distribution of polyaromatic hydrocarbons and polychlorobiphenyls in urban effluents to wastewater treatment plants of the Paris area (France). Water Air Soil Poll 2001;35:3679-3687.

[28] Pham Th-Th, Proulx S. PCBs and PAHs in the Montreal urban community (Quebec, Canada) wastewater treatment plant and in the effluent plume in the St. Lawrence River. Water Res 1997;31(8):1887-1896.

[29] Morris S, Lester JN. Behavior and fate of polychlorinated biphenyls in a pilot wastewater treatment plant. Water Res 1994;28:1553-1561.

[30] Petrasek AC, Kugelman T J, Austern BM, Pressley AT, Winslow LA, Wise RH. Fate of toxic organic compounds in wastewater treatment plants. J Wat Pollut Control Fed 1983;55:1286-1296.

[31] Naiman RJ, Decamps H. (Eds.) The Ecology and Management of Aquatic-Terrestrial Ecotones. UNESCO, MAB, Parthenon, Paris. 1990.

[32] Schiemer F, Zalewski M, Thorpe JE. (Eds) The Importance of Aquatic-Terrestrial Ecotones for Freshwater Fish. Developments in Hydrobiology, 105. Dordrecht, Boston, London: Kluwer Academic Publisher. 1995.

[33] Susarla S, Medina VF, McCutcheon SC. Phytoremediation: an ecological solution to organic chemical contamination. Ecol Eng 2002;18:647-658.

[34] Mitsch WJ, Gosselink JG. Wetlands, 4th edn. New York: John Wiley \& Sons. 2007.

[35] Kiedrzyńska E, Zalewski M. Water quality improvement through an integrated approach to point and non-point sources pollution and management of river floodplain 
wetlands. In: Voudouris K, Voutsa D. (Eds.). Ecological Water Quality - Water Treatment and Reuse. INTECH Open Access, Rijeka, Croatia, 325-342. 2012.

[36] Mitsch WJ, Jørgensen SE. Ecological Engineering and Ecosystem Restoration. New York: Wiley. 2004.

[37] Zalewski m, Robarts R. Ecohydrology - a new Paradigm for Integrated Water Resources Management. SIL News 40, Sep. 2003:1-5.

[38] Zerihun Negussie Y, Urbaniak M, Szklarek S, Lont K, Gągała I, Zalewski M. Efficiency analysis of two sequential biofiltration systems in Poland and Ethiopia - the pilot study. Ecohydrol Hydrobiol 2012;12(4):271-285.

[39] Mackay D, Shiu WY, Ma K-Ch, Lee SC. Handbook of Physical-Chemical Properties and Environmental Fate for Organic Chemicals, Second Edition, Taylor \& Francis Group, LLC, Boca Raton, USA, 2006.

[40] Sewart A, Harrad SJ, McLachlan MS, McGrath SP, Jones KC. PCDDs/Fs and non-o-PCBs in digested UK sewage sludges. Chemosphere 1995;30:51-67.

[41] Eljarrat E, Caixach J, Rivera J. Decline in PCDD and PCDF levels in sewage sludges from Catalonia (Spain). Environ Sci Technol 1999;33:2493-2498.

[42] Dudzińska MR, Czerwiński J. PCDD/F levels in sewage sludge from MWTP in SouthEastern Poland. Organohalogen Comp 2002;57:305-308.

[43] Urbaniak M, Wyrwicka A, Zieliński M, Mankiewicz-Boczek J. Potential for phytoremediation of PCDD/PCDF-contaminated sludge and sediments using Cucurbitaceae plants: a pilot study. Bull Environ Contam Toxicol 2016;97(3):401-406. doi:10.1007/ s00128-016-1868-6

[44] Urbaniak M, Zieliński M, Wyrwicka A. The influence of the Cucurbitaceae on mitigating the phytotoxicity and PCDD/PCDF content of soil amended with sewage sludge. Int J Phytoremediation 2016. doi:10.1080/15226514.2016.1207606

[45] The Federal Ministry of the Environment: Organic pollutants in sewage sludge. The report of the Federal Ministry of the Environment about the need to define additional specific rules-waste list, 1999; 4/99:10-13.

[46] The publication issued by the Ministry of the Environment of Baden-Württemberg (1996): Fourth Administrative Regulation of the Ministry of Environment for the protection of soil, in particular, the identification and classification of the level of organic pollutants in soil (Organic Pollutants) Common Official Journal of BadenWürttemberg of 14 February 1996, n. 2, 87-94, Stuttgart.

[47] Regulation of Lower Austria on sewage sludge and compost waste, Journal of Laws No. 6160 / 1-0 1994. Lower Austria.

[48] The regulation on sewage sludge on 15.04.1992, the Federal Journal of Laws 1992. Part 1, 912-934. 
[49] EU Working Document on Sludge 3rd Draft. Unpublished, 2000; 19 p.

[50] USEPA, 40 CFR Part 503. Standards for the use or disposal of sewage sludge as amended. Proposed Rule 1999.

[51] Wilson SC, Alcock RE, Sewart AP, Jones KC. Persistence of organic contaminants in sewage sludge-amended soil, a field experiment. J Environ Qual 1997;26:1467-1477.

[52] Kearney PC, Woolson EA, Ellington CP. Persistence and metabolism of chlorodioxins in soils. Environ Sci Technol 1972;6:1017-1019.

[53] Field JA, Sierra-Alvarez R. Microbial degradation of chlorinated dioxins. Chemosphere 2008;71:1005-1018.

[54] Barkovskii AL, Adriaens P. Impact of humic constituents on microbial dechlorination of polychlorinated dioxins. Environ Toxicol Chem 1998;17:1013-1020.

[55] Urbaniak M. Biodegradation of PCDD/PCDF and dl- PCB. [In:]: Chamy R, Rosenkran F (Eds) Biodegradation-Engineering and Technology. INTECH Publisher, Rijeka, Croatia, ISBN 978-953-51-1153-5, 73-100, 2013.

[56] Bumpus M, Tien D, Wright SD. Oxidation of persistent environmental-pollutants by a white root fungi. Science 1985;228:1434-1436.

[57] Takada S, Nakamura M, Matsueda T, Kondo R, Sakai K. Degradation of polychlorinated dibenzo-p-dioxins and polychlorinated dibenzofurans by the white root fungus Phanerochaete sordida YK-624. Appl Environ Microbiol 1996;62:4323-4328.

[58] Mackova M, Prouzova P, Stursa P, Ryslava E, Uhlik O, Beranova K, Rezek J, Kurzawova V, Demnerova K, Macek T. Phyto/rhizoremediation studies using long-term PCB contaminated soil. Environ Sci Pollut Res 2009;16:817-829.

[59] Macek T, Macková M, Káš J. Exploitation of plants for the removal of organics in environmental remediation. Biotechnol Adv 2000;18:23-34.

[60] Whipps JM. Carbon economy, [In:] J.M. Lynch (Eds.). The Rhizosphere. New York: Wiley, 1990;59-97.

[61] Lugtenberg BJJ, Dekkers L, Bloemberg GV. Molecular determinants of rhizosphere colonization by Pseudomonas. Annu Rev Phytopathol 2001;39:461-490.

[62] Kuiper I, Lagendijk EL, Bloemberg GV, Lugtenberg BJJ. Rhizoremediation: a beneficial plant-microbe interaction. Mol Plant Microbe Interact 2004;17:6-15.

[63] Siciliano SD, Germida JJ, Banks K, Greer CW. Changes in microbial community composition and function during a polyaromatic hydrocarbon phytoremediation field trial. Appl Environ Microbiol 2003;69:483-489.

[64] Nedunuri KV, Govindaraju RS, Banks MK, Schwab AP, Chen Z. Evaluation of phytoremediation for field-scale degradation of total petroleum hydrocarbons. J Environ Eng 2000;126:483-490. 
[65] Robinson SL, Novak JT, Widdowsen MA, Crosswell SB, Fetterolf GJ. Field and laboratory evaluation of the impact of tall fescue on polyaromatic hydrocarbon degradation in aged creosote contaminated surface oil. J Environ Eng 2002;129:232-240.

[66] Banks MK, Kulakow P, Schwab AP, Chen Z, Rathbone K. Degradation of crude oil in the rizosphere of sorghum bicolor. Int J Phytoremed 2003;5:225-234.

[67] Vervaeke P, Luyssaert S, Mertens J, Meers E, Tack FM, Lust N. Phytoremediation prospects of willow stands on contaminated sediments: a field trial. Environ Pollut 2003;126:7-282.

[68] Wyrwicka A, Steffani S, Urbaniak M. The effect of PCB-contaminated sewage sludge and sediment on metabolism of cucumber plants (Cucumis sativus L.). Ecohyd Hydrobiol 2014;14:75-82.

[69] Antolín MC, Pascual I, García C, Polo A, Sánchez-Díaz M. Growth, yield and solute content of barley in soils treated with sewage sludge under semiarid Mediterranean conditions. Field Crops Res 2005;94:224-237.

[70] Fernández JM, Hockaday WC, Plaza C, Polo A, Hatcher PG, Effects of long-term soil amendment with sewage sludges on soil humic acid thermal and molecular properties. Chemosphere 2008;73:1838-1844.

[71] Lakhdar A, ben Achiba W, Montemurro F, Jedidi N, Abdelly Ch. Effect of municipal solid waste compost and farmyard manure application on heavy-metal uptake in wheat. Commun Soil Sci Plan. 2009;40:3524-3538.

[72] Gawron M. The use of sewage sludge for the restoration of degraded land on the background of planning decisions and legal requirements. Environmental Engineering 2007; 13:103-109.

[73] Singh RP, Agrawal M. Potential benefits and risks of land application of sewage sludge. Waste Manage 2008;28:347-358.

[74] Aki C, Güneysu E, Acar O. Effect of industrial wastewater on total protein and the peroxidase activity in plants. Afr J Biotechnol 2009;8:5445-5448.

[75] Antolín MC, Muro I, Sánchez-Díaz M. Application of sewage sludge improves growth, photosynthesis and antioxidant activities of nodulated alfalfa plants under drought conditions. Environ Exper Bot 2010;68:75-82.

[76] Antolín MC, Muro I, Sánchez-Díaz M. Sewage sludge application can induce changes in antioxidant status of nodulated alfalfa plants. Ecotoxicol Environ Saf 2010;73:436442.

[77] Mittler R. Oxidative stress, antioxidants and stress tolerance. Trends Plant Sci. 2002;7:405-410.

[78] Kuzniak E, Skłodowska M. The effect of Botrytis cinerea infection on the antioxidant profile of mitochondria from tomato leaves. J Exper Bot 2004;55:605-612. 
[79] Mittler R, Zilinskas B. Regulation of pea cytosolic ascorbate peroxidase and other antioxidant enzymes during the progression of drought stress and following recovery from drought. Plant J 1994;5:397-405.

[80] Hernández JA, Campillo A, Jiménez A, Alarcón JJ, Sevilla F. Response of antioxidant systems and leaf water relations to $\mathrm{NaCl}$ stress in pea plants. New Phytol 1999;141:241251.

[81] Kang H-M, Saltveit ME. Activity of enzymatic antioxidant defence systems in chilled and heat shocked cucumber seedling radicles. Physiol Plant 2001;113:548-556.

[82] Foyer CH, Vanacker H, Gomez LD, Harbinson J. Regulation of photosynthesis and antioxidant metabolism in maize leaves at optimal and chilling temperatures: review. Plant Physiol Biochem 2002;40:659-668.

[83] Blokhina OB, Chirkova TV, Fagerstedt KV. Anoxic stress leads to hydrogen peroxide formation in plant cells. J Exper Bot 2001;52:1179-1190.

[84] Gajewska E, Skłdowska M. Effect of nickel on ROS content and antioxidative enzyme activities in wheat leaves. BioMetals 2007;20:27-36.

[85] Mackerness SA. Plant responses to ultraviolet-B (UV-B: 280-320 nm) stress: what are the key regulators? Plant Growth Regul 2000;32:27-39.

[86] Chernikova T, Robinson JM, Lee EH, Mulchi CL. Ozone tolerance and antioxidant enzyme activity in soybean cultivars. Photosynth Res 2000;64:15-26.

[87] Wyrwicka A, Skłodowska M. Intercompartmental differences between cytosol and mitochondria in their respective antioxidative response and lipid peroxidation levels in acid rain stress. Acta Physiol Plant 2014;36:837-848.

[88] Zhang B, Zhang H, Jin J, Ni Y, Chen J. PCDD/Fs-induced oxidative damage and antioxidant system responses in tobacco cell suspension cultures. Chemosphere 2012;88:798-805.

[89] Gill SS, Tuteja N. Reactive oxygen species and antioxidant machinery in abiotic stress tolerance in crop plants. Plant Physiol Biochem 2010;48:909-930.

[90] Foyer $\mathrm{CH}$, Noctor G. Redox homeostasis and antioxidant signaling: a metabolic interface between stress perception and physiological responses. Plant Cell 2005;17:1866-1875.

[91] Wyrwicka A, Urbaniak M. The different physiological and antioxidative responses of zucchini and cucumber to sewage sludge application. PLoS One 2016;11:e0157782. doi: 10.1371/journal.pone.0157782

[92] Oleszczuk P. Testing of different plants to determine influence of physico-chemical properties and contaminants content on municipal sewage sludges phytotoxicity. Environ Toxicol 2010;25:38-47. 
[93] Materac M, Wyrwicka A, Sobiecka E. Phytoremediation techniques in wastewater treatment. Environ Biotechnol 2015;11:10-13.

[94] Reischl A, Reissinger M, Thoma H, Hutzinger O. Uptake and accumulation of PCDD/F in terrestrial plants: basic considerations. Chemosphere 1989;19:467-474.

[95] Buckley EH. Accumulation of airborne polychlorinated biphenyls in foliage. Science 1982;216:520-522.

[96] Gaggi C, Bacci E. Accumulation of chlorinated hydrocarbon vapours in pine needles. Chemosphere 1985;14:451-456.

[97] Hülster A, Müller JF, Marschner H. Soil-plant transfer of polychlorinated dibenzo-pdioxins and dibenzofurans to vegetables of the cucumber family (Cucurbitaceae). Environ Sci Technol 1994;28:1110-1115.

[98] Inui H, Sawada M, Goto J, Yamazaki K, Kodama N. A major latex-like protein is a key factor in crop contamination by persistent organic pollutants. Plant Physiol 2013;161:2128-2135.

[99] Briggs GG, Bromilow RH, Evans AA. Relationships between lipophilicity and root uptake and translocation of non-ionised chemicals by barley. Pesticide Sci 1982;13:495504.

[100] Kew GA, Schaum JL, White P, Evans TT. Review of plant uptake of 2,3,7,8-TCDD from soil and potential influences of bioavailability. Chemosphere 1989;18:1313-1318.

[101] Trapp S, Matthies M. Generic one-compartment model for uptake of organic chemicals by foliar vegetation. Environ Sci Technol 1995;29:2333-2338.

[102] Trapp S, Matthies M. Modeling volatilization of PCDD/F from soil and uptake into vegetation. Environ Sci Technol 1997;31:71-74.

[103] Welsch-Pausch K, McLachlan M, Umlauf G. Determination of the principal pathways of polychlorinated dibenzo-p-dioxins and dibenzofurans to Lolium multiflorum (Welsh Ray Grass). Environ Sci Technol 1995;29:1090-1098.

[104] Hülster A, Marschner H. Transfer of PCDD/PCDF from contaminated soils to food and fodder crop plants. Chemosphere 1993;27:439-446.

[105] Uegaki R, Seike N, Otani T. Polychlorinated dibenzo-p-dioxins, dibenzofurans, and dioxin-like polychlorinated biphenyls in rice plants: possible contaminated pathways. Chemosphere 2006;65:1537-1543.

[106] Müller JF, Hülster A, Päpke O, Ball M, Marschner H. Transfer pathways of PCDD/PCDF to fruits. Chemosphere 1993;27:195-201.

[107] Müller JF, Hülster A, Päpke O, Ball M, Marschner H. Transfer of PCDD/PCDF from contaminated soils into carrots, lettuce and peas. Chemosphere 1994;29:2175-2181. 
[108] McCrady JK, McFarlanea C, Ganderb LK. The transport and fate of 2,3,7,8-TCDD in soybean and corn. Chemosphere 1990;21:359-376.

[109] Wild SR, Jones KC. Organic chemicals entering agricultural soils in sewage sludges: screening for their potential to transfer to crop plants and livestock. Sci Total Environ 1992;119:85-119.

[110] Wagrowski DM, Hites RA. Polycyclic aromatic hydrocarbon accumulation in urban, suburban, and rural vegetation. Environ Sci Technol 1997;31:279-282.

[111] Trapp M, McFarlane C. Plant Contamination. Boca Raton: Lewis Publishers; 1995.

[112] Briggs GG. Theoretical and experimental relationships between soil adsorption, octanol-water partition coefficients, water solubilities, bioconcentration factors, and the parachor. J Agric Food Chem 1981;29:1050-1059.

[113] Briggs GG, Bromilow RH, Evans AA, Williams M. Relationships between lipophilicity and the distribution of non- ionised chemicals in barley shoots following uptake by the roots. Pesticide Sci 1983;14:492-500.

[114] Collins C, Fryer M, Grosso A. Plant uptake of non-ionic organic chemicals. Environ Sci Technol 2006;40:45-52.

[115] Govers H, Krop H. Partition constants of chlorinated dibenzofurans and dibenzo-pdioxins. Chemosphere 1998;37:2139-2152.

[116] Lovett AA, Foxall CD, Creaser CS, Chewe D. PCB and PCDD/DF congeners in locally grown fruit and vegetable samples in Wales and England. Chemosphere 1997;34:14211436.

[117] Engwall M, Hjelm K. Uptake of dioxin-like compounds from sewage sludge into various plant species - assessment of levels using a sensitive bioassay. Chemosphere 2000;40:1189-1195.

[118] White JC, Parrish ZD, Isleyen M, Gent MPN, Iannucci-Berger W, Eitzer BD, Kelsey JW, Mattina MI. Influence of citric acid amendments on the availability of weathered PCBs to plant and earthworm species. Int J Phytoremediation 2005;8:63-79.

[119] Inui H, Wakai T, Gion K, Kim YS, Eun H. Differential uptake for dioxin-like compounds by zucchini subspecies. Chemosphere. 2008;73:1602-1607.

[120] White JC. Differential bioavailability of field-weathered $p, p^{\prime}$-DDE to plants of the Cucurbita and Cucumis genera. Chemosphere 2002;49:143-152.

[121] White JC, Wang X, Gent MPN, Iannucci-Berger W, Eitzer BD, Schultes NP, Arienzo M, Mattina MI. Subspecies-level variation in the phytoextraction of weathered $p, p^{\prime}$-DDE by Cucurbita pepo. Environ Sci Technol 2003;37:4368-4373. 
[122] Mattina MI, Eitzer BD, Iannucci-Berger W, Lee WY, White JC. Plant uptake and translocation of highly weathered, soil-bound technical chlordane residues: data from field and rhizotron studies. Environ Toxicol Chem 2004;23:2756-2762.

[123] Mattina MJI, Iannucci-Berger W, Dykas L. Chlordane uptake and its translocation in food crops. J Agric Food Chem 2000;48:1909-1915.

[124] Oleszczuk P, Baran S. Polycyclic aromatic hydrocarbons content in shoots and leaves of willow (Salix viminalis) cultivated on the sewage sludge-amended soil. Water, Air Soil Pollut 2005;168:91-111. 
